\title{
PENGUATAN PARTISIPASI DIDALAM AKUNTABILITAS PEMBANGUNAN DESA
}

\author{
Agus Prianto \\ Universitas Yudharta Pasuruan \\ Email: \\ prianto211183@gmail.com
}

\begin{abstract}
Autonomous systems change and change (amendment) as the goal of accelerating development amidst social change. Based on Law 23 of 2014, the authority of the Village Government to design development in accordance with the needs of the community that requires the existence of public participation. Principles of Participation in Development make the system of Democracy a moral development and as a mechanism of social system of development in the village. The high participation of Masyasrakat can create accountability in the function of the Village Command by institutionalizing the community able to play an active role in the planning and supervision of village development.
\end{abstract}

Key words: Participation; Intitution; Accountability

\section{PENDAHULUAN}

Atas dasar peraturan Otonomi Nomor 23 Tahun 2014 tersebut maka otonomi desa benar nyata adanya, yakni kewenangan desa untuk mengatur dan mengurus urusan rumah tangganya sendiri yang didasarkan hak-hak yang bersumber dari adat istiadat. kosenkuensi pada peraturan otonomi tersebut sebagaimana pemerintah pusat mulai mengalirkan dana ke desa sebagaimana Undang Undang Nomor 06 Tahun 2014 tentang pemerintah daerah yang memiliki azas Peraturan Pemerintah Nomor 113 tahun 2014 tentang pengelolaan keuangan desa.

Secara administrasi desa (Sadu, 2006) memiliki tujuan atas otonomi desa yang berprinsip pada luas nyata dan bertanggung jawab yang tertuang dalam penggunaan wewenang pemerintah desa untuk membuat keputusan didasarkan pada norma hukum admnitrasi yaitu norma umum dan norma khusus, pemerintah desa dan Tentang Pedoman Pengelolaan keuangan Daerah, sebagaimana telah diubah dengan Peraturan Menteri Dalam Negeri Nomor 59 Tahun 2007 Tentang Perubahan Atas Peraturan Menteri
Dalam Negeri Nomor 13 Tahun 2006 Tentang Pedoman Pengelolaan Keuangan Daerah. Pada Intinya semua peraturan tersebut menginginkan adanya transparansi dan akuntabilitas dalam pengelolaan keuangan daerah yang semata mata hanya untuk menciptakan Negara yang Demokrasi.

Mewujudkan sistem Demokrasi sangatlah lama, terutama belum ada totalitas akan komitmen disemua pilar demokrasi baik pada level Pemerintahan desa, Masyarakat dan BPD (Badan Perwakilan Desa) sekarang ini, dari ketiga elemen tersebut masih belum mencerminkan akan nilai komitmen membangun nilai akuntabilitas pertama; pemerintah dalam proses akutabilitas kebijakan penganggaran masih banyak memakai system Top Down dalam membuat kebijakan perencanaan Kedua; masyarakat sipil tidak dapat mencerminkan sikap sebagai fungsi yang semestinya yakni penyeimbang pemerintahan dalam merumuskan kebijakan dengan menyampaikan aspirasi rakyat ketiga; kurang optimalnya Fungsi BPD sebagai pengayom, perwakilan masyarakat desa (legislative), Pengawasan (control), yang secara kongkrit BPD bersama-sama 
pemerintah desa membentuk peraturan desa, menetapkan APBD desa. Dan memberikan pertimbangan kepada pemerintah desa terhadap rencana perjanjian antar desa dengan pihak ketiga dan pembentukan Badan Usaha Milik Desa.

Dari ketiga elemen institusionalisasi birokrasi desa hal yang terpenting dalam menciptakan nilai akuntabilitas dalam penganggaran yang memiliki koherensi untuk menciptakan pembangunan di desa adalah wujud partisipatif, sebab ranah partisipasi menjadi hal penting dalam pembangunan, baik pada tingkatan nasional, regional dan lokal (brenkerhoff dan Crosby, 2002.p.53).

Tujuan otonomi desa semuanya itu mengarah pada pelayanan pada masyarakat yang mengutamakan pada kepentingan pada tingkat bawah grass roat. Dasar filosofi tersebut tentang pelayanan publik dimaksudkan agar pelayanan oleh negara terhadap rakyatnya semakin baik, akan tetapi banyak terjadi praktik maladministrasi yang dilakukan oleh aparatur birokrasi mulai pusat, daerah hingga desa, terutama pada urusan pelayanan publik (dalam laporan Ombusmen, 2009) yang mengakibatkan banyak urusan publik yang tidak bisa diselesaikan dengan baik sehingga merugikan dan terganggunya kepentingan masyarakat. Hampir disetiap instansi pemerintahan desa masih bisa didapati buruknya pelayanan pubik, syarat alokasi anggaran adanya korupsi, pembangunan yang out of the conteks dari nilai masyarakat, pembangunan berbasis pada konstituen, dan berpusat pada infrastruktur / mal Nutrisi anggaran.

Secara teoritis sedikitnya ada tiga fungsi utama yang harus dijalankan oleh pemerintah (Pemerintahan Desa) tanpa memandang tingkatannya, yaitu public service function (fungsi pelayanan masyarakat), development function (fungsi pembangunan), dan proctection function (fungsi perlindungan). Fungsi pelayanan masyarakat lebih berkaitan dengan pelaksanaan tugas-tugas umum pemerintahan, fungsi pembangunan mendudukkan pemerintah sebagai agen pembangunan, terutama dalam merangsang dan mendorong pembangunan, untuk meningkatkan taraf hidup warganya. sedangkan fungsi perlindungan memberikan peran kepada pemerintah untuk melindungi warganya baik dari gangguan alam maupun gangguan yang disebabkan oleh manusia. Selain tiga fungsi tersebut di atas, ada fungsi regulasi (pengaturan) dimana desa diharap mampu membuat peraturan desa / Perdes.

Dalam memahami problem akuntablitas public penyelenggaraan adminitrasi di desa maka perlu mengkaji tentang upaya dalam membangun akuntabilitas public dalam penyelenggaraan pemerintah desa dan melembagakan institusionalisasi partisipasi dalam mewujudkan akuntabilitas Anggaran. Konteks masalah tersebut sebagaimana mewujudkan reformasi birokrasi desa dengan melakukan perubahan struktur dan meningkatkan peranan masyarakat dalam mencerminkan tatakelola pemerintah desa yang baik (good governance).

\section{KAJIAN TEORI}

\section{Akuntabilitas \\ Anggaran dalam Penyelenggaraan Pemerintahan Desa}

Demokrasi merupakan bentuk tatanan ideal namun sulit dalam mewujudakan bila belum ada totalitas akan komitmen disemua pilar demokrasi baik Pemerintahan desa, dan Masyarakat, sekarang ini dari ketiga elemen itu masih belum mencerminkan akan nilai komitmen membangun nilai akuntabilitas pertama; pemerintah desa dalam proses perencanaan pembangunan masih Top Down; Kedua; masyarakat belum secara optimal dalam mengikuti dan menyalurkan aspirasi guna memberikan input terhadap perumusan 
kebijakan didesa. Saya kira hal yang terpenting dalam menciptakan nilai akuntabilitas dalam penganggaran yang bagaimana menciptakan pembangunan di dearah yang berbasis partisipatif ??. sebab dalam paham negara demokratis kontrol rakyat terhadap penyelenggara pemerintahan desa, merupakan terjemahan yang sempurna dari azas kedaulatan rakyat.

Pada awalnya kontrol masyarakat terhadap penyelenggara pemerintahan desa "diejawantahkan" di dalam model democration Representatif. Namun dalam perkembangannya demokrasi repesentatif dapat terjerumus ke dalam pemerintahan elitarisme, di mana keputusan keputusan penting hanya diambil oleh segelintir orang saja (Model Elite). Oleh karenanya, sangat rawan terhadap praktek-praktek penyelewengan kekuasaan (parktek $\mathrm{KKN}$ ) dan terjadinya perselingkuhan birokrasi dengan kapitalisme dan terciptanya kesejangan pembangunan, tingginya korupsi di tingkat pemerintah desa, terjadinya malnutrisi, melanggar ketetapan hukum dalam menentukan anggaran, dan penyelewengan anggaran.

Dalam perkembangan otonomi harus menciptakan dimensi - dimensi akuntability sebagaimana berikut; 1) Policy Acuntability; apakah orientasi kebijakan pemerintah kearah pro-poor atau jender sensitive. 2) Pelaksanaan Anggaran sudah benar; dalam pendistribusian anggaran sudah tepat dalam melaksanakan maupun tagert dan tujuannya serta menilai damak dari program pemerintah. 3) Kepastian terhadap hukum; kesesuaian pembuatan anggaran public terhadap hukum. 4) Nilai Efisiensi; apakah kegiatan itu Malnutrisi / anggran tidak merata (ketimpanagan). 5) Akutanbility Proses; dalam pembuatan kebijakan umum anggaran itu terbuat atau didominasi oleh Top-down atau Buttom-Up. Dalam hal ini kontrol masyarakat dalam penyelenggaraan urusan pemerintah desa harus dapat bersifat langsung dan nyata. Kontrol msyarakat terhadap penguasa hanya dapat berjalan efektif, bila penyelenggara negara dapat memaparkan program dan kebijakannya secara transparan sebab Partisipasi masyarakat merupakan bentuk pengambilan keputusan dalam proses penyusunan dan penetapan APBD Desa, sehingga masyarakat mengetahui akan hak dan kewajibannya dalam pelaksanaan APBD Desa.

Tuntutan akuntabilitas bukannya hanya semata dari segi politis namun juga pada penganggaran bagaimana menentukan ABPD Desa yang menjadi pokok dasar dalam melakukan pembangunan sebagai modal untuk pemenuhan dan pemberdayaan masyarakat. Terlebih lagi sekarang adanya system pemerintahan yang otonomi seperti yang dijelaskan dalam Penjelasan Umum Undang-Undang Nomor 23 Tahun 2014 bahwa penyelenggaraan pemerintah daerah mempunyai prinsip sebagai berikut: demokratis, keadilan, pemerataan, potensi dan keanekaragaman daerah selain itu dalam Pelaksanaan otonomi daerah harus lebih meningkatkan peranan dan fungsi badan legislatif daerah, baik fungsi legislatif, fungsi pengawas maupun fungsi anggaran atas penyelenggaraan pemerintah daerah.

Dalam mewujudkan akuntabilitas terhadap keuangan pemerintah desa sangat rumit dan pelik, ada 4 (empat) pilar agar proses akuntabilitas sosial bisa berjalan dan terwujud, yaitu 1). adanya kelompokkelompok masyarakat yang terorganisir dan berkemampuan; 2). pemerintah yang responsif; 3). kesesuaian budaya dan konteks, 4). akses terhadap informasi. Indonesia mempunyai peluang yang besar untuk membangun akuntabilitas sosial di tengah masyarakatnya sekarang. Yaitu dengan terbentuknya Komisi Informasi sebagai implementasi dari disahkannya UU No. 
14/2008 tentang keterbukaan informasi publik menjadikan akses informasi.

Sejalan dengan undang-undang otonomi yang memberikan kewenangan desentralisasi untuk mengatur akan rumah tangga didaerah (pembangunan) juga terdapat kewenangan akan kebijakan fiscal yang mengatur tentang penganggaran public terkait dengan pajak, subsidi pemerintah dan kebijakan pembelanjaan. Desentralisasi ini diharapkan akan menghasilkan dua manfaat nyata (Mardiasmo,2005;25) yaitu: pertama, mendorong peningkatan partisipasi, prakarsa dan kreativitas masyarakat dalam pembangunan, serta mendorong pemerataan hasil-hasil pembangunan (keadilan) di seluruh daerah dengan memanfaatkan sumber daya dan potensi yang tersedia di masing-masing daerah. Kedua, memperbaiki alokasi sumber daya produktif melalui pergeseran peran pengambilan keputusan publik ke tingkat pemerintahan yang paling rendah yang memiliki informasi yang paling lengkap.

Untuk melakukan pengawasan akan akuntabilitas keuangan pemerintah daerah maka dapat dengan menggunakan 4 cara; Budget Formulation (Lihat bagaimana anggaran publik dirumuskan dan dialokasikan); Budget Review (Diagnosis implikasi anggaran terhadap kepentingan public); Expenditure Tracking (Lacak kemana uang pergi); dan Performance Monitoring (output \& outcome)

\section{Institusionalisasi Partisipasi dalam Menciptakan Akutabilitas Anggaran}

Paritisipasi sangat erat dengan HAM (Ife, 2008,p.312) dimana pertisipasi terdorong oleh: pertama, orang berartisipasi apabila mereka merasa bahwa isu atau aktivitas terebut penting, kedua, orang harus merasa aksi mereka akan membuat perubahan, ketiga,berbagai partisipasi harus diakui dan dihargai, keempat, orang hurus bisa berpartisipasi dan didukung dalam partisipasinya. Melihat pendorong partisipasi pemerintah harus bisa menempatkan keberadaan pemerintah dalam masyarakat yang Plural.

Konsepsi yang mendasari partisipasi adalah Institusional sebab letaknya pada pardigma norma dan legitimasi, sebagaimana yang di sebut oleh Hegel Sittlitkheit yakni institusi bersumber dari social dan moral. Insitusi juga sebagai proses cara berfikir dan sosiokultur sebagaimana dijelaskan oleh Maggio dan Powell (dalam Donalsond 1995) bahwa institusi organisasi terbentuk melalui proses mimicry atau imitasi dan compliance yang dalam pendekatannya bisa dalam bentuk ishomorphis dengan memahami atas berdirinya organisasi didasari oleh norma dan aturan di masyarakat, sehingga berdirinya organisasi dilatarbelakangi kondisi social.

Ditengah kondisi perubahan social masyarakat dipedesaan, tidak lepas dengan adanya empat pilar institusi didalam tatakelola pemerintah yang baik sebagaimana melihat atas institusi itu baik good Institution ataupun Institusi miskin Poor Institution. Sebagaimana pilar Regulatif yang menyangkut kelembagaan sebagai pembuat aturan didalam organisasi pemerintah, pilar Normatif sebagai cara tindakan manusia di organisasi, dan pilar kognitif sebagai cara pandang manusia di dalam sebuah organisasi. Pandangan ini sebagaimana dijelaskan oleh Adam Smith (1999) sebagai Institusi social yang memiliki maksud bahwa pengejaran kepentingan diri akan menciptakan tatanan social.

Tatanan social menjadi sebuah rekayasan sosial maka tak lepas peran masyarakat, sebagaimana peran masyarakat secara nyata dipengaruhi oleh tingkat kesadaran manusia sebagaimana Sudjana (1991) konsep mengenai penyadaran atau conscientization digunakan untuk 
membangkitkan kesadaran diri warga masyarakat terhadap lingkungannya. Oleh sebab itu diperlukan adanya pemberdayaan dengan mengembalikan atau memberi dan atau mengakui keberadaan masyarakat oleh rezim pemerintahan menurut, Rahman (2009,p.94) pemberdayaan ialah berusaha memberikan kekuasaan lebih dulu kepada rakyat. Penerapannya dimulai dengan tingkat pemerintahan dari pada masyarakat terlebih dahulu karena dinegara berkembang (indonesia) terdapat permasalahan yang pelik yang disebabkan akan kemiskinan struktural sehingga sering mengaburkan dalam partisipasi dimana sering kali, program kebijakan tanpa melalui agregrasi artikulasi akan kepentingan masyarakat yang hanya pada wilayah transaksi dan action, sehingga tak jarang kebijakan pemerintah kurang bisa relevan terhadap kebutuhan.

Dan ada serta ruang yang mensyaratkan untuk ikut serta dalam pembangunan (pasrtisipasi) Rahnema dalam Muluk (2007) partisipasi sebagai "the action or fact of parkling, heaving or forming a port of" dalam pengertian ini bersifat transitif atau intransitif dapat pula bermoral atau tidak bermoral, kandungan pertisipasi juga dapat bersifat dipaksa atau bebas dan dapat pula bersifat memanipulatif atau spontan demikian ini dipengaruhi tingkat kemampuan masyrakat dalam ruang publik sebagai wujud partisipasi warga negara.

Dengan kegiatan partisipasi pemerintah dapat meletakkan masyarakat sebagai objek pembangunan, sehingga menciptakan tata kelola pemerintahan yang baik, transparansi, akuntabilitas dana inovatif, demikian ini mencerminkan tatanan pemerintah good governance (Dwiyanto, 2009,p.19) mempunyai karakteristik, pertama: memberikan ruang aktor lembaga non pemerintahan untuk berperan dalam kegiatan pemerintah, kedua: adanya nilai - nilai yang mengandung untuk mewujudkan kesejahteraan bersama, ketiga: adanya pemerintahan yang bersih. Proses diatas tak lepas hanya untuk manajemen pembanguna yang keberlanjutan, dimana proses pemberdayaan merupakan investasi terhadap kemajuan negara dimasa yang akan datang.

\section{METODOLOGI}

Penelitian berobjek reformasi Administrasi Desa menggunakan pendekatan kualitatif yang bersifat deskriptif. Penelitian ini bertujuan memberi gambaran atau paparan terhadap peristiwa yang diteliti tentang Akuntabilitas Publik dalam penyelenggaraan pemerintahan desa dengan menghadirkan peran masyarakat sebagai institusional. Pengumpulan data dalam penelitian ini dilakukan dengan observasi atau pengamatan terhadap objek Denszin dan Nicolin (2009.). Disamping itu, pengumpulan data juga melalui studi kepustakaan (library research) yang juga disebut sebagai teknik dokumentasi yang ditunjukkan untuk menggambarkan fenomena-fenomena apa adanya. Dalam penelitian ini, deskriptif yang dimaksud adalah analisis media dengan deskriptif kualitatif.

\section{PEMBAHASAN}

\section{Akuntabilitas Anggaran Pemerintah Desa}

Akutanbilitas Anggaran menjadi sebuah keharusan didalam penyelenggaraan dan penggunaan uang Negara, tujuan akuntabilitas dalam keuangan (Anggaran) Pemerintah Desa sebagai upaya atas tata kelola keuangan harus memiliki program yang strategis. Nilai strategis dapat dilihat sebagaimana out put dan impact program pemerintah desa disusun untuk mengatasi atas pelayanan publik. Apa yang terjadi di desa sebenarnya menunjukan bagaimana pola keuangan di desa yang dilakukan oleh perangkat desa yang mana perencanaanya 
harus di susun dengan bersama masyarakat desa karena Dalam pelaksanaan dan pengelolaan Keuangan Desa harus dikelola berdasarkan azas-azas transparan, akuntabel, partisipatif serta dilakukan dengan tertib dan disiplin anggaran.

Tata kelola Anggaran Publik oleh pemerintah desa sudah diatur didalam Undang-Undang Nomor 6 Tahun 2014 yang mengatur Tentang Desa sebagaimana hak dan kewajiban desa yang dinilai dengan uang serta segala sesuatu berupa uang dan barang yang berhubungan dengan pelaksanaan hak dan kewajiban Desa. Sebagaimana Hak dan
Kewajiban tersebut menimbulkan adanya pendapatan, belanja dan pembiayaan yang perlu diatur dalam pengelolaan keuangan desa yang baik. Tatakelola keuangan desa dapat dipahami sebagaimana siklus pengelolaan keuangan desa meliputi perencanaan, pelaksanaan, penatausahaan, pelaporan, dan pertanggungjawaban sebagaimana petunjuk Pelaksanaan Bimbingan dan Konsultasi Pengelolaan Keuangan Desa Oleh: Deputi Bidang Pengawasan Penyelenggaraan Keuangan Daerah, 2015:33)

\section{Gambar. 1. Siklus Tata Kelola Keuangan Pemerintah Desa}

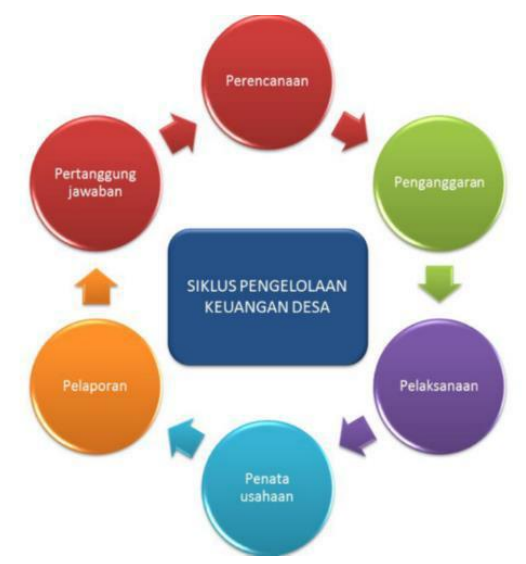

Sumber: BPKP. Juklak Bimkon Pengelolaan Keuangan Desa, 2015)

Dari beberapa bagian didalam siklus datas, terdapat penguatan partisipasi masyarakat pada bagaian perencanaan, penganggaran dan pelaksanaan. Penguatan pada bagian perencanaan Desa meliputi RPJM Desa dan RKP Desa yang di susun secara berjangka dan ditetapkan dengan peraturan desa itu sendiri. Rencana Pembangunan Jangka Menengah Desa disebutnya sebagai RPJM Desa dengan kurun masa berlaku 6 (enam) tahun sedangkan Rencana Kerja Pemerintah Desa disebutnya sebagai RKP Desa dengan masa 1 (satu) tahun.
Mekanismen menyusun RPJM/RKP Desa berkewajiban turut serta didalam proses Musyawarah Perencanaan Pembangunan Desa (Musrenbangdes) dilakukan secara partisipatif dengan melibatkan atas keterwakilan masyarakat dalam perumusan dan perencanaan pembangunan sebagai bentuk buttom up sebagaimana Enviorepment Policy. Untuk mengetahui perencanaan yang harus sesuai dengan unsur-unsur didalam perencanaan itu sendiri yaitu perencanaan harus dilaksanakan dengan adanya upaya pemerintah desa melakukan musyawarah, melibatkan BPD (Badan Perwakilan Desa). melibatkan unsur masyarakat, atas 
dilaksanakannya Musdes dan Musrembangdes.

Proses musdes dan atau musrenbangdesa sebagai proses counter ide dan gagasan dari tingkat bawah sebagai perwujudan aspirasi dirumuskan dari masyarakat dusun bahkan dari setiap data yang ada terkait perencanan seperti Pendapatan Asli Desa Maupun Dana Transfer, sebagaimana Pagu Indikatif selalu disosialisakan kepada masyarakat hal ini sangat baik dalam Konteks Pemerintahan yang Transparan dan Akuntabel. Meskipun dalam tataran implementatifnya pagu indikatif dianggap menjadi acuan pokok dalama penyusunan program.

Sebagaimana proses Musdes dan Musrenbang masih kuat dipengaruhi akan sumber daya manusia yang masih menganut sistem social patrialkhis (cultur NU), meskipun di pasuruan terdapat perda partisipasi Nomor 17 Tahun 2015 tentang sebagaimana pasal 1 menjelaskan bahwa pembangunan partisipasi merupakan peran masyarakat didalam pembangunan yang direncanakan, dilaksanakan, diawasi dan dilestarikan sendiri oleh masyarakat berdasarkan aspirasi dan kebutuhannya, dimana Pemerintah sebagai fasilitator, aturan tersebut mengharuskan adanya partisipasi didalam pembangunanan. Peran masyarakat dalam pembangunan menjadi subjek sehingga penerapan didalam prinsip pembangunan senantiasa berbasis pada kebutuhan masyarakat, menjadi sebuah fenomena dan gejala baru atas proses musrenbang

Pelaksanaan keuangan desa harus mengacu pada prinsip-prinsip umum, sebagaimana kaitannya penerimaan dan pengeluaran desa dilaksanakan melalui rekening kas desa. Untuk mengetahui pelaksanaan pengelolaan keuangan yang akuntabel perlu mengkomparasikan dalam pelaksanaan pengelolaan keuangan yang harus sesuai dengan unsur-unsur didalam.
Dan tidak kalah pentingnya didala pelaksanaan pengelolaan keuangan itu sendiri harus dilaksanakan dengan adanya pencatatan oleh bendahara terkait peneriamaan dan pengeluaran keuangan desa, adanya penerimaan dan pengeluaran harus melalui rekening Desa, adanya persetujuan dari Kepala Desa dalam pencairan keuangan desa.

\section{Parasit Sistem pada Pemerintah Desa}

Tujuan otonomi desa sebagai bentuk peningkatan kesejahteraan dimasing masing wilayah dan juga adanya beberapa bentuk dana alokassi dana desa (ADD) yang bersumber dari APBD Kabupaten Pasuruan dan sumber lain dari Pendapatan dari usaha desa (BUMDes). Keuangan Pemerintah Desa dikabupaten pasuruan perputaran dalam satu Tahun minimal desa menerima sekitar Rp 1,33 Milyar Dijelaskannya, dana sebesar $\mathrm{Rp}$ 1,12 milliar yang akan diterima oleh masingmasing desa. Yakni, terdiri dari tiga sumber. Pertama dari Dana Desa (DD) yang berasal dari APBN, nilainya mencapai $\mathrm{Rp}$ 632,35 juta/desa."Kemudian, Alokasi Dana Desa (ADD) yang berasal dari APBD Kabupaten Pasuruan yang nilainya mencapai Rp 426,44 juta/desa. Ditambah lagi dari dana bagi hasil pajak dan retribusi daerah yang nilainya mencapai Rp70,86 juta/desa. Hal ini merupakan suatu sinyal posisitf dan komitmen pemerintah pusat akan kejelasan kebijakan fiscal di aras local dan akan mempermudah dan mempercepat akan pembangunan dan penyetaraan dari setiap daerah.

Namun dalam desentralisasi fiscal (versi Orde Reformasi) memunculkan banyak daerah yang mempunyai tanggung jawab besar namun tidak diiringi dengan kapasitas fiskal yang memadai dalam perumusan anggran dan lemahnya sumber daya manusia aparatur pemerintah dalam mengelola 
anggran public sehingga memunculkan bentuk prilaku kecederungan patologi anggaran, sebagai berikut;

a. Sistem perencanaan didesa masih menggunakan jasa orang lain, yang notabane dokumen perencanaan pembangunan desa jauh dari azas kebutuhan masyarakat.

b. Malnutrisi dengan ketidak teralokasikan dana akibat kurang bisa adakan bentuk program jelas dan tepat yang dapat menyerap dana desa sehigga terjadi penumpukan dana pada program tertentu.

c. Tidak transparan dan system informasi yang asimetris dari musrenbang tidak sesuai pada tataran hasil di Musdes dan Musrenbangdes.

d. Distribusi program masih berkutat pada basis konstituen

e. Korupsi muncul sebab mengawasi dan juga celah akan kelemahan administrasi kuangan di pemerintah desa.

Aparatur Desa se Kab. Pasuruan sebanyak 4671 orang yang belum lulus SMA sederajat sekitar 30\%. Dan mayoritas melanjutkan pendidikan lewat kejar paket. Rendahnya Sumberdaya Manusia berdampak lemahnya system pengawasan dalam penggunaan anggaran, sehingga muncul praktek patologi sehingga sulit sekali adanya perwujudan akuntabilitas pada proses desentralisasi fiscal pada pelaksanaan Otonomi Desa. Bila menilik dari kejadian adanya penumpukan dana didesa dan adanya sanksi administrasi SILPA (pemotongan angaaran tahun berikutnya) berdampak pada pengurangan anggaran ditahun berikutnya, mendorong prilaku pemerintah desa identik tidak taat kelola keuangan publik, serta kurang optimalnya partisipasi masyarakat mendorong tindakan korupsi terstructur di tingkat pemerintah desa.

Peningkatan Dana Desa semestinya diikuti oleh peningkatan kesejahteraan masyarakat yang dicerminkan lewat Pembangunan Manusia (IPM) Pasuruan yang tiap tahun kenaikan 0,02\% (sumber; BPS 2016), banyaknya alokasi belanja publik untuk peningkatan kesejahteraan masyarakat menunjukkan bahwa Belanja Aparatur dan belanja publik (APBDesa) berpengaruh secara signifikan pertumbuhan ekonomi sebab memiliki hubungan timbal- balik yang positif.

Penganggaran dalam konteks ekonomi berkedudukan sangat penting, sebab didalam penganggaran oleh pemerintah desa belum menganggarkan kegiatan selama setahun dengan meknisme Analisis Standart Belanja ABS (UU No 32 tahun 2004) sebagaimana penilaian kewajaran atas beban kerja dan biaya yang digunakan untuk melaksanakan kegiatan berbasis kebutuhan masyarakat, maksudnya usaha penilaian terhadap kewajaran atas beban kerja dan biaya terhadap suatu kegiatan guna mengukur kinerja keuangan dengan beban kerja program atau kegiatan yang dinilai kewajarannya. berdasarkan pertimbangan sebagai berikut;

1. Kaitan logis antara program atau kegiatan yang diusulkan dengan strategi dan prioritas;

2. Kesesuaian antar program atau kegiatan yang diusulkan dengan tugas pokok dan fungsi satuan kerja yang bersangkutan;

3. Kapasitas pelaksana Program yang bersangkutan untuk melaksanakan program atau kegiatan pada tingkat pecapaian yang diinginkan dan dalam jangka waktu satu tahun anggaran;

\section{Penguatan Institusi Peran Masyarakat Dalam Akuntabilitas}

Fungsi kebijakan fiscal yakni untuk mempercepat pembangunan diaras lokal (desa), sebagaimana didalam prakteknya menekankan prinsip Democratic Governance yang indikatornya ada kebijakan pro poor and partisipatory, sebagai paradigma dalam 
penyusunan anggaran public untuk menyeimbangkan anggaran Governance sustanibility (sustanibelitas fiskal), didalam pengembangan Public Sektor (mengelola sector public). Maka peningkatan Anggaran Pendapatan Belanja Desa, semestinya diikuti oleh peningkatan kesejahteraan masyarakat yang dicerminkan lewat tingginya produktifitas masyarakat yang salah satunya diukur pendapatan per kapita per tahun dan/ Indeks Pembangunan Manusia (IPM). alokasi belanja publik untuk peningkatan kesejahteraan masyarakat menunjukkan APBDesa berpengaruh secara signifikan terhadap PDRB per kapita sebab disetiap pengeluaran Pemerintah Desa dan tingkat pertumbuhan ekonomi mempunyai hubungan timbal- balik yang positif.

Penganggaran dalam prespektif prilaku ekonomi berkedudukan sangat penting, sebab didalam penganggaran terdapat kebijakan pemerintah dalam menganggarkan kegiatan selama setahun RKP Desa yang dibiayai oleh uang public dengan meknisme ASB (Analisis Standart Belanja) bedasarkan Pasal 16 Permendagri 113 Tahun 2014 tentang Pemerintah Desa bahwa Belanja Modal Desa digunakan untuk pengeluaran dalam rangka pembelian/pengadaan barang atau bangunan yang nilai manfaatnya lebih dari 12 (dua belas) bulan. Ukuran kegunaan 12 bulan memiliki kelemahan atas regulasi tersebut yang berkaitan dengan upaya pemerintah desa didalam pengelolaan dan belanja keuangan desa dalam analisis standar belanja terkait dengan beban kerja program atau kegiatan yang diusulkan dalam RKPDesa masih berkaitan dengan infrastruktur dapat dinilai kewajarannya berdasarkan pertimbangan logis antara program atau kegiatan yang diusulkan dalam RKP Desa dengan strategi Visi Misi dan prioritas APBDesa.

Sebagaimana azas penyelenggaraan pemerintah desa Perda Nomor 06 Tahun 2015
Tentang Pemerintah desa harus berlandaskan pada azas (Pasal 2); (a) rekognisi; (b) subsidiaritas; (c) keberagaman; (d) kebersamaan; (e) kegotongroyongan; (f) kekeluargaan; $(g)$ musyawarah; $(h)$ demokrasi; (i) kemandirian; (j) partisipasi; ( $k$ ) kesetaraan; (l) pemberdayaan; dan $(m)$ keberlanjutan. Dalam pelaksanaan penganggaran public di pemeritah desa, perumusan dan implementasi program Desa harus melibatkan atas partisipasi masyarakat sebagaimana Perda Pemerintah Desa.

Sebagaimana yang diamanatkan dalam Undang-undang 23 Tahun 2014 Pasal 354. Pada ayat 1 diharapkan mendorong partisipasi masyarakat maka pemerintah daerah harus; a) menyampaikan informasi tentang penyelenggaraan Pemerintah Daerah kepada masyarakat; $b$ ) mendorong kelompok dan organisasi masyarakat untuk berperan aktif dalam penyelenggaraan Pemerintah Daerah melalui dukungan pengembangan kapasitas masyarakat; c) mengembangkan kelembagaan dan mekanisme pengambilan keputusan yang memungkinkan kelompok dan organisasi kemasyarakatan dapat terlibat secara aktif; dan/atau d) kegiatan lainnya sesuai dengan ketentuan peraturan perundang-undangan. Sehingga dalam pembangunan desa aspek partisipasi masyarakat sebagaimana menciptakan akuntabilitas publik pada perencanaan, penganggaran, pelaksanaan, pemonitoran, dan pengevaluasian pembangunan daerah.

Sementara itu, bentuk partisipasi masyarakat dikabupaten pasuruan masih dipengaruhi oleh budaya masyarakat pasuruan yang patrialkhis dan tingkat partisipasi masih di tentukan oleh stratifikasi social sebagaimana teori birokrasi repesentatatif (Dwight Waldo, 1952 dalam Federicson, 2012: 60) yang menganggap birokrasi hirarkhis dan authotarian (Max Weber) dapat rekonsiliasi dengan sistem egaliter sehingga mampu menciptakan 
Demokratisasi maka dalam tataran sebuah sistem administrasi dalam sistem Negara yang berproses demokratis dapat juga mengelaborasi dengan sistem yang patriarkhis.

\section{Kolaborasi birokrasi representative} yang berfokus kepada penemuan atas legitimasi kekuatan politik mampu berkolaborasi dengan sistem sosial dikabupaten pasuruan yang berbudaya pada patrialkhis, meskipun dalam beberapa penelitian meragukan atas budaya patrialkhis mampu mendorong sistem pemerintahan yang demokratis. Kemampuan kolaboratif tersebut mampu menerima nilai masyarakat ditengah keragaman masyarakat sehingga berfungsi lebih memungkinkan untuk merespon kepentingan seluruh kelompok masyarakat didalam proses pengambilan kebijakan. Kemampuan atas akomodir nilainilai masyarakat akan lebih fleksibel melihat keragamanan masyarakat pluralistic dan kebijakan pemerintah akan lebih bisa kompromis dengan tujuan pemerintah dan kebutuhan masyarakat di aras local masyarakat desa.

Peluang representatif birokrasi yang mampu berkolaborasi dengan sistem sosial akan menciptakan sistem demokrasi local, sebagai sebuah institusi dipengaruhi oleh ekonomi, sosial dan politik, yang mampu mempengaruhi disain institusi politik yang mengkonstruksi sosial, peranan, norma dan prilaku masyarakat secara individu maupun kelompok sehingga sistem budaya patrialkhispun dapat mendorong masyarakat untuk berpartisipasi. Sebagaimana kita ketahui bahwa budaya dikabupaten pasuruan cenderung menempatkan ulama', atau orang yang memiliki pengaruh sebagai patron dan masyarakat umum menjadi klien (followers).

Konteks Sang patron pun menjadi sebuah panutan didalam pengambilan keputusan rational choice, oleh sebab perlu memberikan ruang pada sang patron untuk menjadi instrument didalam proses pembangunan, sebagaimana sebuah institusi mengakomodir secara keseluruhan tentang kepentingan diri atau kompetitif. Dengan upaya melihat sebuha partisipasi sebagai sebuah institusi mengarahkan atas peran patron mejadi penggerak/mobilisasi partisipasi masyarakat klien sebagai upaya akomodir nilai - nilai masyarakat.

\section{KESIMPULAN}

Sebaaimana yang diamantkan pada per Undang-undang 23 Tahun 2014 Pasal 354. Pada ayat 1 diharapkan mendorong partisipasi masyarakat didalam pemerintah, mejadi prinsip dan komitmen didalam proses pembangunan, salah satunya menjadi Prinsip pengelolaan keuangan desa yang harus berazaskan pada partisipasi; kesetaraan; pemberdayaan; dan keberlanjutan. Sebagaimanya azas tersebut diamanahkan didalam Perda Nomor 06 Tahun 2015, menganggarkan kegiatan selama setahun yang dibiayai oleh uang publik dengan meknisme ASB (Analisis Standart Belanja) yang Belanja Modal Desa digunakan untuk pengeluaran dalam rangka pembelian/pengadaan barang atau bangunan yang nilai manfaatnya lebih dari 12 (dua belas) bulan mendorong perencanaan pemerintah desa melakukan perencanaan tanpa melibatkan masyarakat.

Problem dimasyarakat juga pada proses rasionlitas didalam ruang partisipasi masyarakat dimana kehendak peraturan masyarakat diberi ruang untuk berpartisipasi, namun sebab rendahnya SDM dan ditengah budaya patronklien, terdapat prilaku atas partisipasi semu sebab rationalitas terbatas masyarakat, rendahnya tingkat partisipasi masyarakat menjadi penyebab rendahnya atas pengawasan dan buruknya sistem akuntabilitas public. Oleh sebab itu diperlukan sebuah penguatan partisipasi 
masyarakat melalui pelembagaan masyarakat pasuruan.

Proses pelembagaan / institusional partisipasi menjadi upaya adanya bentuk birokrasi representative dengan memberikan model sistem demokrasi local, yang syarat dengan pemberdayaan masyarakat patrialkhi dengan menciptakan model partisipasi yang dimulai adanya sang patron untuk mangakomodir nilai - nilai dimasyarakat. Sehingga memunculkan peran serta untuk turut memonitoring dan mengevaluasi program di desa.

\section{DAFTAR PUSTAKA}

Brinkerhoff, D. W., \& Crosby, B. L. (2002). Managing Policy Reform. Kumaria press Inc.

Donaldson, L. (1995). American AntiManagement of Paradigma paradigm Proliferasion. Cabridge University Press.

Dwiyanto, A. (2006). Mewujudkan Good Governance Melalui Pelayanan Publik. Yogyakarta: Gama Press.

Fredericson, \& Kevin, S. (2012). The Public Adminitration Theory Primer. WestView Press.

Guy, P. B., \& Pierre, J. (2007). Handbook of Public Administration (First Edition). London: Sage Publication.

Hikam, M. A. (1996). Demokrasi dan Civil Society. Jakarta: LP3ES.

Ife, J., \& C., F. T. omunity Development. Yogyakarta: Pustaka Pelajar.

Pranoto, E. (n.d.). Maladministrasi Akibat Hukum Dan Penyelesaiannya (makalah tanpa tahun). Retrieved from http://edipranoto.blogspot.com/2011/ 02/maladministrasi-akibat-hukumdan.html,25/07/11

Putra, F. (2009). Senjakala Good Governance. Malang: Puspeks Averrous.

Rohman, A. (2009). Politik partisipasi dan demokrasi dalam pembangunan. Malang: Averoes.

Sudjana, H. (1991). Pendidikan Luar Sekolah: Wawasan Sejarah Perkembangan Falsafah dan Teori Pendukung Asas. Bandung: Penerbit Nusantara Pres.

Wasistiono, S. (2006). Prospek Pengembangan Desa, Lembaga Kajian Manajemen Pemerintah Daerah. Fokus Media.

Sumber Lain:

1. Gerald E Caiden dalam eko Prasojo http/infokorupsi.com/id/opinion.php

2. Pengelolaan Keuangan Desa; Sistem dan Prosedur PertanggungJawaban

Keuangan Desa dalam http:/ /.kemenkeu.go.id/diakses 20/10/2017

3. Sumber: BPS Kabupaten Pasuruan /Statistic Indonesia of Pasuruan Regency

Peraturan perundang-Undangan

1. Undang-Undang Nomor 6 Tahun 2014 Tentang desa. Pasal 23, Pasal 72, Ayat (1)

2. Permendagri Nomor 113 Tahun 2014 Tentag Pengelolaan Keuangan Desa Di Unduh di https://www.jogloabang.com/pustaka/ permendagri-113-tahun-2014pengelolaan-keuangan-desa 